\title{
Pengiriman Daya dari Inverter Lima Tingkat ke Grid Satu Fasa Menggunakan Arduino Due
}

\author{
Iwan Kristiawan $^{1}$ dan Leonardus Heru Pratomo ${ }^{2}$ \\ Program Studi Teknik Elektro, Universitas Katolik Soegijapranata \\ Jl. Pawiyatan Luhur IV/1, Semarang, 50234, Indonesia \\ iwankristiawan54@gmail.com ${ }^{1}$,leonardus@unika.ac.id ${ }^{2}$
}

\begin{abstract}
Inverter has been used for a wide variety of applications in renewable energy system. The use of inverter in a sol ar power plant system can off-grid and on-grid. H-Bridge inverter is one of the commonly used inverter. One of its disadvantages is the requirement of high frequency in order to get a low defect level on the output current. The use of a five-level inverter with considering the amount of a power semiconductor switch in can be as an alternative. This study aims to use a five-level inverter with five power semiconductor switches to deliver power to the grid. The working principle uses two sinusoidal signals that are shifted by $180^{\circ}$ compared to two carrier signals to produce a sinusoidal pulse width modulation signal. A sinusoidal pulse width modulation signal is used as a controller on each power semiconductor switch. The transmitted power is in the form of a current that is injected into the singlephase grid. The transmission of a power using five-level inverter to a single-phase grid was val idated by a Power Simulator software. The final stage was a hardware implementation in the laboratory. The result

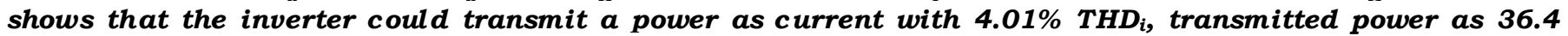
Watts, and transmitted current as 0.52 Amps.
\end{abstract}

Keywords- power, five-level inverter, on-grid, $\mathrm{THD}_{i}$

\begin{abstract}
Abstrak- Inverter telah digunakan untuk berbagai macam aplikasi dalam sistem energi baru terbarukan. Penggunaan inverter dalam sistem PLTS dapat berupa off-grid dan on-grid. H-bridge inverter merupakan salah satu inverter yang lazim digunakan. Salah satu kekurangan inverter tersebut adalah penggunaan frekuensi tinggi agar mendapatkan tingkat kecacatan yang rendah pada sisi arus keluaran. Penggunaan inverter lima tingkat dengan pertimbangan jumlah sakelar daya dapat digunakan sebagai alternatif. Penelitian ini bertujuan untuk menggunakan inverter lima tingkat dengan lima sakelar daya untuk mengirimkan daya ke grid. Prinsip kerja menggunakan dua buah sinyal sinusoidal yang saling bergeser sebesar 1800 dibandingkan dengan dua sinyal pembawa untuk menghasilkan sinyal modulasi lebar pulsa sinusoidal. Sinyal modulasi lebar pulsa sinusoidal digunakan sebagai pengendali pada setiap sakelar daya. Daya yang dikirimkan berupa besaran arus yang diinjekkan ke grid satu fasa. Pengiriman daya menggunakan inverter lima tingkat ke grid satu fasa divalidasi dengan menggunakan simulasi perangkat lunak Power Simulator. Tahap akhir dilakukan implementasi perangkat keras di laboratorium. Hasil yang diperoleh adalah inverter dapat mengirimkan daya dalam bentuk arus dengan nilai THD $_{i} 4,01 \%$, daya dikirim sebesar $36,4 \mathrm{~W}$ att, dan arus dikirim sebesar 0,52 Ampere.
\end{abstract}

Kata kunci-daya, inverter lima tingkat, on-grid, THD $_{\mathrm{i}}$

\section{PEndahuluan}

Sumber energi listrik saat ini banyak digunakan. Dengan bertambah banyaknya pengguna, maka dibutuhkan energi alternatif lain yang disebut dengan energi baru terbarukan (EBT) atau renewable energy [1]. Sumber EBT yang sedang dikembangkan seperti pembangkit listrik tenaga air, angin, surya, dan biogas. Pembangkit Listrik Tenaga Surya (PLTS) diterapkan untuk berbagai aplikasi misalnya perumahan, industri, dan kendaraan listrik [2]. Penggunaan inverter dalam sistem PLTS dapat berupa off-grid dan on-grid. Pada sistem on-grid, energi yang dihasilkan oleh PLTS terhubung dengan jaringan listrik PLN dan juga digunakan untuk mensuplai beban peralatan listrik [3]. Sistem PLTS on-grid dibagi menjadi single stage [4] dan dual stage [5]. Single stage menggunakan satu konverter sedangkan dual stage menggunakan dua konverter. Panel surya atau photovoltaic (PV) pada sistem PLTS menghasilkan bentuk listrik direct current (DC). Pengaplikasian dalam sistem distribusi kelistrikan yang umum digunakan adalah sumber alternating current (AC). Untuk mengubah sumber listrik DC menjadi sumber listrik AC digunakan sebuah perangkat yang dinamakan inverter.

Inverter yang memiliki kualitas daya yang baik dan efisien menjadi perhatian besar para peneliti [6]. Inverter yang lazim digunakan adalah $\mathrm{H}$-Bridge inverter. Kele mahan dari inverter jenis ini harus menggunakan frekuensi tinggi agar mendapatkan tingkat kecacatan yang rendah pada sisi keluaran arus [7]. Inverter bertingkat menjadi solusi untuk mendapatkan kualitas daya yang baik dengan menggunakan 
frekuensi rendah. Inverter bertingkat memiliki kelebihan jika dibandingkan dengan inverter konvensional [8]. Inverter bertingkat memiliki keuntungan seperti produksi daya yang lebih tinggi, kualitas bentuk gelombang keluaran, dan kemampuan tegangan tinggi. Tetapi juga memiliki kerugian seperti jumlah sakelar daya yang lebih banyak dan metode kontrol modulasi lebar pulsa sinusoidal dapat mempengaruhi distorsi harmonik [9].

Inverter sumber tegangan bertingkat secara luas terdiri dari tiga kelompok utama yaitu inverter bertingkat-dioda atau konverter multi-jep it [10], inverter bertingkat-kapasitor atau inverter multi-sel [11], dan cascade inverter atau H-bridge bertingkat [12]. Setiap kelompok memiliki kontrol yang berbeda [13]. Kontrol yang digunakan dapat berupa unipolar atau bipolar [14]. Metode kontrol yang digunakan akan mempengaruhi kualitas bentuk gelombang dari inverter tersebut. Kontrol unipolar memiliki distorsi harmonik yang lebih rendah dibandingkan dengan bipolar [15]. Selain inverter sumber tegangan terdapat juga inverter sumber arus. Inverter sumber arus menggunakan tapis induktor.

Tujuan dari penelitian ini adalah mengirimkan daya ke grid satu fasa menggunakan inverter lima tingkat. Metode penelitian diimp le mentasikan dengan mikrokontroller Arduino Due. Kendali kontrol unipolar dipakai pada setiap sakelar daya. Untuk membuat arus keluaran inverter lima tingkat sesuai dengan arus referensi yang diinginkan, digunakan kendali tipe proposional integral (PI). Inverter lima tingkat diharapkan menghasilkan $\mathrm{THD}_{\mathrm{i}}$ sesuai standart IEEE 519 menggunakan frekuensi yang rendah dan tapis induktor yang kecil dibandingkan dengan inverter konvensional [7]. Inverter lima tingkat yang diteliti mempunyai lebih sedikit sakelar daya daripada inverter lima tingkat lainnya (misal pada [16]). Sehingga rugi pensakelaran dapat dikurangi.

\section{METODE}

Metode yang digunakan dalam penelitian ini meliputi kajian teori, perumusan masalah, simulasi, dan implementasi inverter lima tingkat, seperti ditunjukkan pada Gambar 1. Kajian teori dilakukan terkait peran inverter dalam sistem ongrid ke mudian dirumuskan permasalahan penggunaan inverter pada sistem on-grid. Simulasi komputasi dilakukan untuk memastikan konsep yang diteliti berjalan. Langkah terakhir adalah membuat perangkat keras dan melakukan pengujian terhadap data yang diambil.

Inverter pada sistem on-grid berfungsi sebagai perangkat keras yang menginjekkan daya dalam besaran arus. Sehingga diperlukan inverter yang arus keluarannya terkendali. Kandungan harmonisa arus $\left(\mathrm{THD}_{\mathrm{i}}\right)$ harus memenuhi standart IEEE 519. Untuk mendapatkan nilai $\mathrm{THD}_{\mathrm{i}}$ sesuai standart IEEE, inverter dioperasikan pada fre kuensi yang tinggi. Solusi yang ditawarkan adalah menggunakan inverter bertingkat. Inverter bertingkat memiliki jumlah sakelar daya yang banyak. Sedangkan inverter lima tingkat yang diteliti hanya memakai lima sakelar daya.

Dapat dilihat pada Gambar 2, jika arus inverter lebih besar dari arus beban maka arus inverter akan menuju ke jaringan listrik. Jika arus inverter lebih kecil dari arus grid maka arus inverter menuju ke beban. Hubungan antara $I_{\text {load }}, I_{\text {inverter }}$, dan $I_{\text {grid }}$ dinyatakan sebagai berikut:

$$
\begin{gathered}
I_{\text {load }}=I_{\text {grid }}+I_{\text {inverter }} \\
I_{\text {inverter }}=I_{\text {load }}-I_{\text {grid }} \\
I_{\text {grid }}=I_{\text {load }}-I_{\text {inverter }}
\end{gathered}
$$

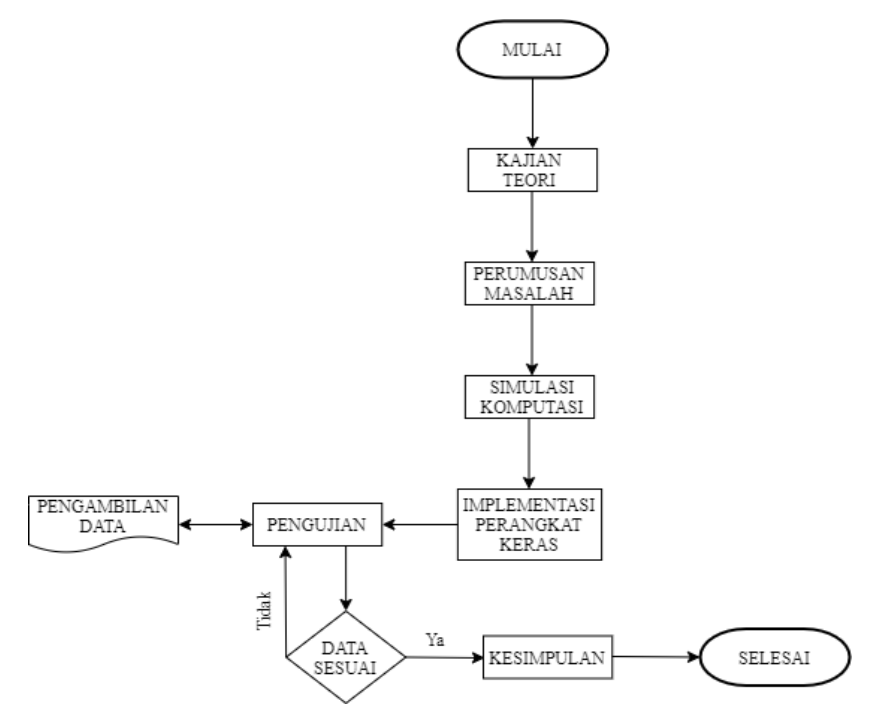

Gambar 1. Diagram alir metode penelitian

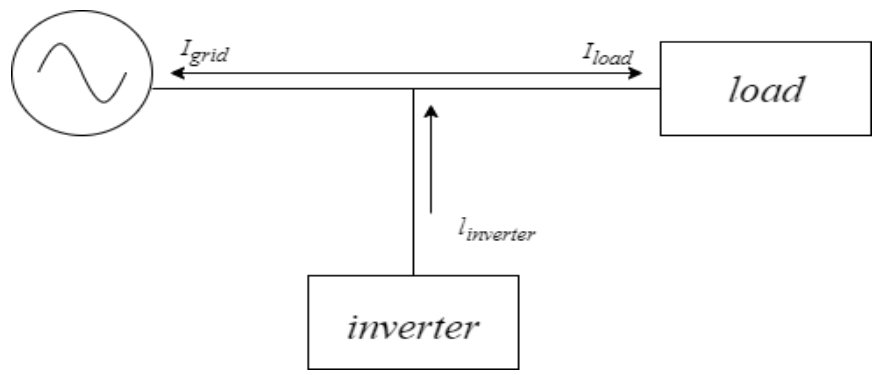

Gambar 2. Pengiriman arus inverter pada sistem on-grid

Pada penelitian ini, inverter lima tingkat terdiri dari dua buah sumber tegangan (V1) dan (V2), lima buah sakelar daya (S1, S2, S3, S4, dan S5), tapis induktor (L), satu dioda (D1), dan beban (R). Gagasan ini telah disimulasikan dengan desain seperti Gambar 3. Sakelar daya (S1) disebut sebagai pembentuk tingkat pada polaritas positif dan negatif $2 \mathrm{E}$. Sakelar daya (S2 - S5) sebagai pembentuk tingkat E. Dalam penerapan pensakelarannya rangkaian inverter lima tingkat terdiri dari 5 mode operasi yaitu mode operasi satu, mode operasi dua, mode operasi tiga, mode operasi empat, dan mode operasi lima [17].

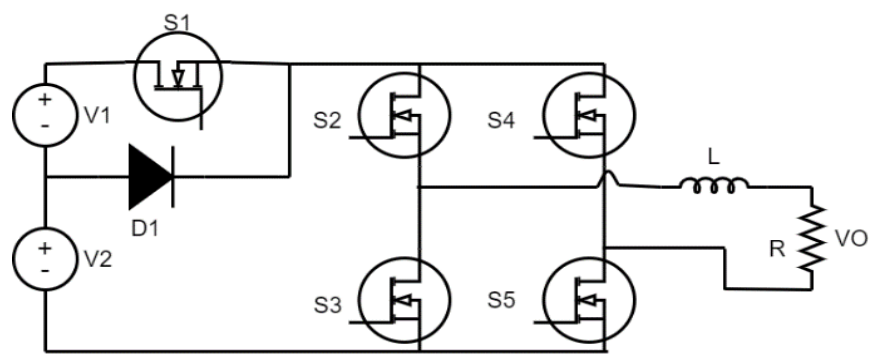

Gambar 3. Topologi rangkaian inverter lima tingkat 
Pada mode operasi satu menghasilkan keluaran sebesar 2E di mana S1, S2, dan S5 aktif sedangkan S3 dan S4 mati. Gambar 4 menunjukkan jalur arus yang aktif pada mode operasi satu. Arus mengalir dari V2 menuju V1, melalui S1, S2, tapis induktor dan beban lalu S5 dan kembali ke V2. Persamaan pada mode operasisatu sebagai berikut:

$$
\begin{gathered}
E-E=V_{(L)}+V_{(o)} \\
L \frac{d i_{(1)}}{d t}=2 E-V_{(o)} \\
L \Delta i_{(L)}=\left(2 E-V_{(o)}\right) \Delta t=\left(2 E-V_{(o)}\right)
\end{gathered}
$$

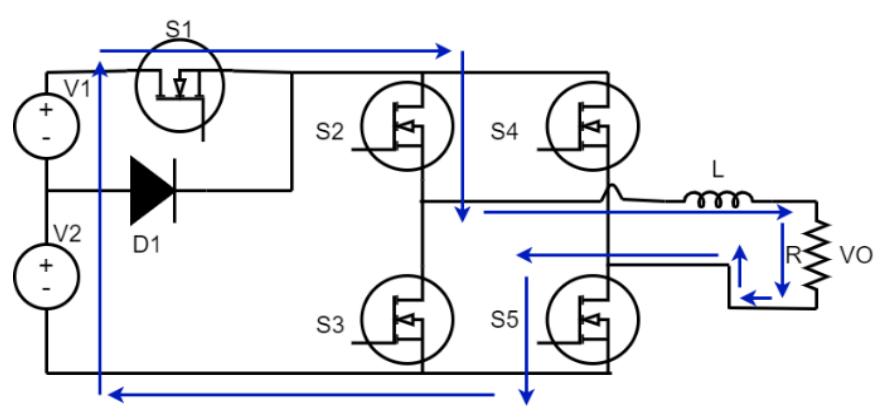

Gambar 4. Mode operasi satu, saat sakelar S1, S2, dan S5 konduksi

Pada operasi dua menghasilkan keluaran sebesar E di mana S2 dan S5 akt if sedangkan S3, S4, dan S5 mati. Gambar 5 menunjukkan jalur arus yang akt if pada mode operasi dua. Arus mengalir dari V2 menuju S2, tapis induktor, dan beban lalu S5 dan kembali ke V2. Persamaan pada mode operasi dua sebagaiberikut:

$$
\begin{gathered}
E=V_{(L)}+V_{(o)} \\
L \frac{d i_{(1)}}{d t}=E-V_{(o)} \\
L \Delta i_{(L)}=\left(E-V_{(o)}\right) \Delta t=\left(E-V_{(o)}\right) t_{(o n)}
\end{gathered}
$$

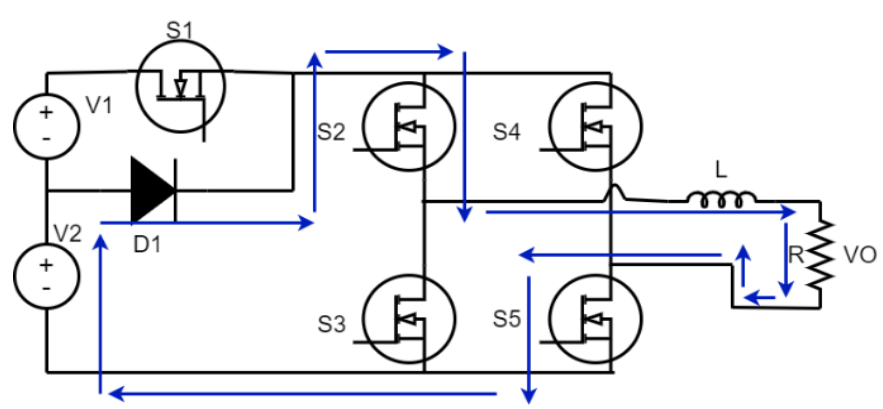

Gambar 5. Mode operasi dua, saat sakelar S2 dan S5 konduksi

Pada mode operasi tiga adalah kondisi freewheeling, menghasilkan dua keluaran sebesar nol. Pada siklus positif S2 dan S4 aktif sedangkan S1, S3, dan S5 mati. Gambar 6(a) menunjukkan jalur arus yang aktif pada tahap ini. Arus dari tapis induktor menuju beban, melalui S4 dan S2, kemudian kembali ke tapis induktor. Pada siklus negatif S3 dan S5 akt if sedangkan S1, S2, dan S4 mati. Gambar 6(b) menunjukkan jalur arus yang aktif pada mode operasi tiga. Arus dari tapis induktor menuju S3, S5 lalu ke beban. Persamaan pada mode operasi tiga sebagai berikut:

$$
V_{(L)}=V_{(o)}-V_{(d)}
$$

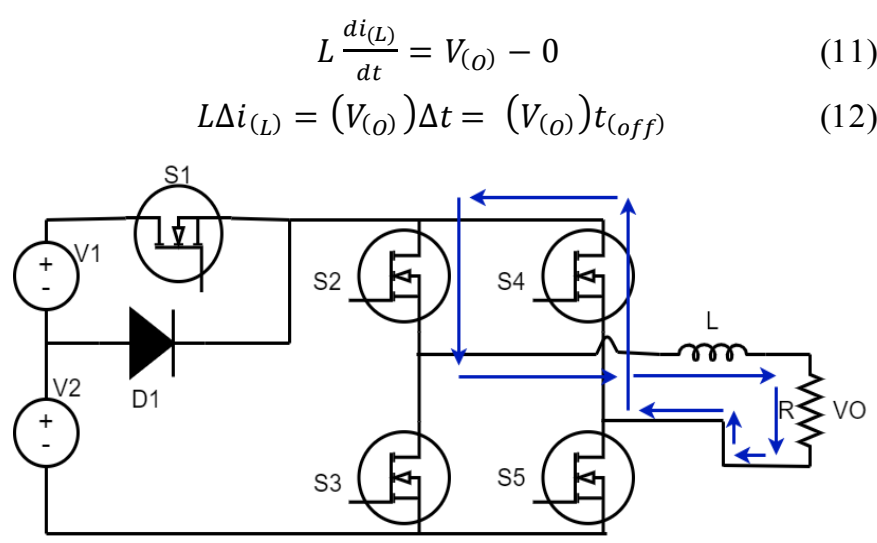

(a)

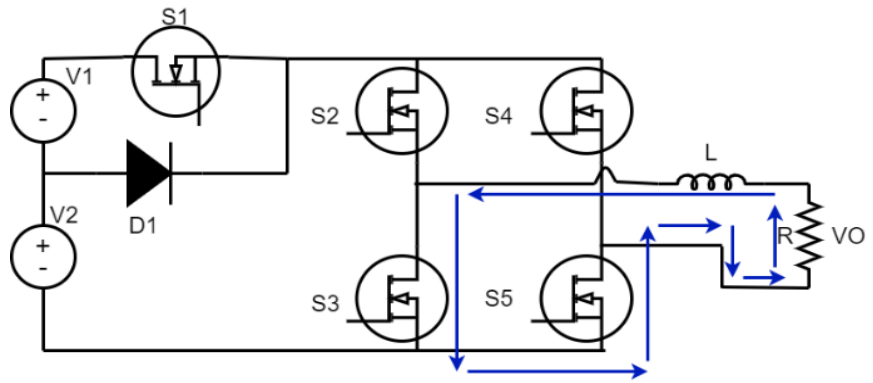

(b)

Gambar 6. Mode operasi tiga. (a) siklus positif, saat sakelar S2 dan S4 konduksi, (b) siklus negatif, saat sakelar S3 dan S5 konduksi

Pada mode operasi empat menghasilkan keluaran sebesar -E di mana S3 dan S4 aktif sedangkan S1, S2, dan S5 mati. Gambar 7 menunjukkan jalur arus yang aktif pada tahap ini. Arus mengalir dari V2 menuju dioda, S4, beban, tapis induktor, S3 lalu kembali ke V2. Persamaan pada mode operasi empat sebagaiberikut:

$$
\begin{aligned}
& -E=V_{(L)}+V_{(o)} \\
& L \frac{d i_{(L)}}{d t}=V_{(o)}-E
\end{aligned}
$$$$
L \Delta i_{(L)}=\left(V_{(o)}-E\right) \Delta t=\left(V_{(o)}-E\right) t_{(o n)}
$$

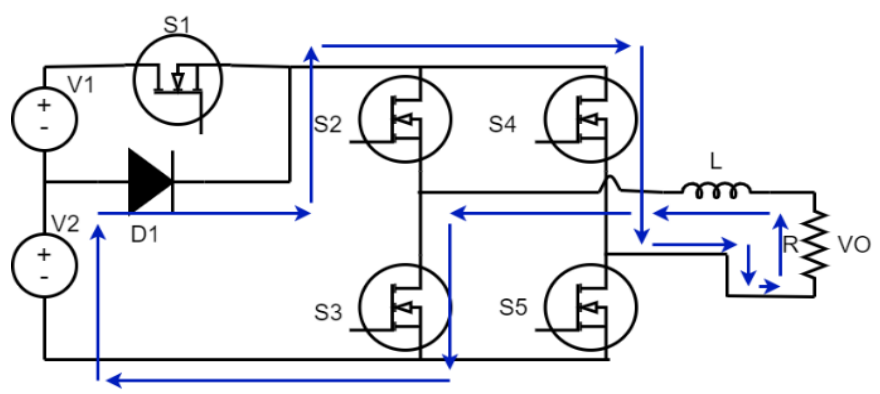

Gambar 7. Mode operasi empat, saat sakelar S3 dan S4 konduksi

Pada mode operasi lima menghasilkan keluaran sebesar -2E di mana S1, S3, dan S4 akt if sedangkan S2 dan S5 mati. Gambar 8 menunjukkan jalur arus yang aktif pada tahap ini. Arus mengalir dari V2 menuju V1, S1, S4, beban, tapis induktor, S3 dan kembali ke V2. Persamaan pada mode operasi lima sebagaiberikut:

$$
-(E-E)=V_{(L)}+V_{(o)}
$$




$$
\begin{gathered}
L \frac{d i_{(1)}}{d t}=V_{(o)}-2 E \\
L \Delta i_{(L)}=\left(V_{(o)}-2 E\right) \Delta t=\left(V_{(o)}-2 E\right) t_{(o n)}
\end{gathered}
$$

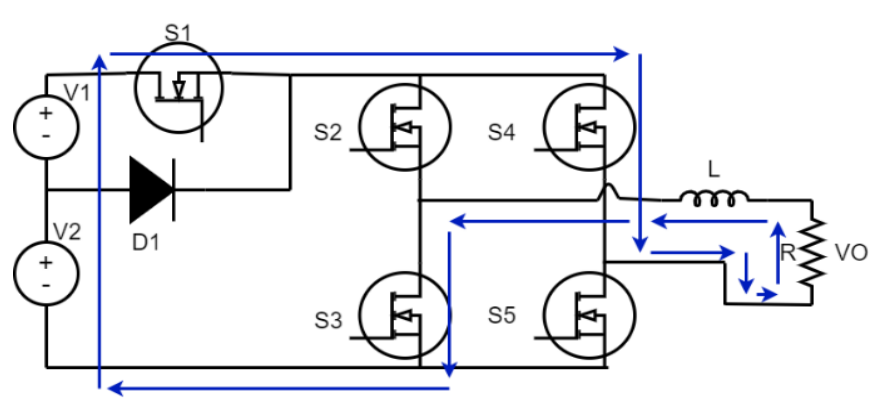

Gambar 8. Mode operasi lima, saat sakelar S1, S3, dan S4 konduksi

Berdasarkan mode operasi satu sampai mode operasi lima, maka didapatkan pola pensakelaran seperti pada Tabel I. Blok diagram sistem kendali inverter lima tingkat ditunjukkan pada Gambar 9.

TABEL I. POLA PENSAKELARAN INVERTER LIMA TINGKAT

\begin{tabular}{|c|c|c|c|c|}
\hline S1 & S2 & S3 & S4 & S5 \\
\hline 1 & 1 & 0 & 0 & 1 \\
\hline 0 & 1 & 0 & 0 & 1 \\
\hline 0 & 1 & 0 & 1 & 0 \\
\hline 0 & 0 & 1 & 0 & 1 \\
\hline 0 & 0 & 1 & 1 & 0 \\
\hline 1 & 0 & 1 & 1 & 0 \\
\hline
\end{tabular}

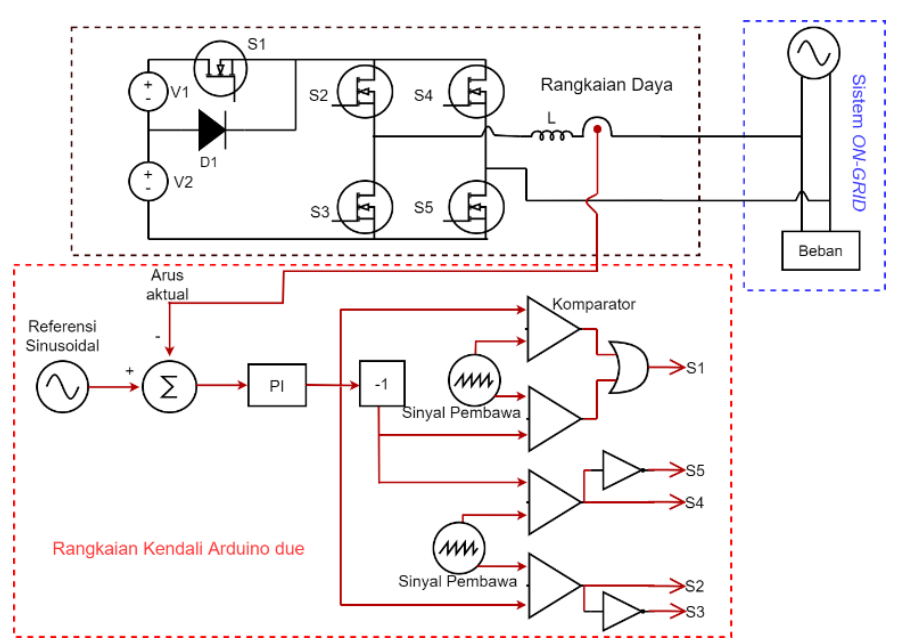

Gambar 9. Blok diagram sistem kendali inverter lima tingkat

Berdasarkan Gambar 9 dilakukan suatu pemograman perangkat lunak dengan menggunakan Arduino IDE yang diimplementasikan pada mikrokontroller Arduino Due. Referensi sinusoidal merupakan referensi arus dan arus aktual adalah hasil dari keluaran sensor arus. Kendali yang digunakan adalah kendali PI. Sinyal keluaran kontrol di modulasi dengan sinyal pembawa sehingga menghasilkan modulasi lebar pulsa sinusoidal. Bentuk sinyal pensakelaran pada tiap sakelar daya ditunjukkan pada Gambar 10.
Pada Gambar 10, strategi kontrol modulasi lebar pulsa sinusoidal menggunakan dua sinyal pembawa bertingkat dan sinyal referensi berupa satu gelombang sinusoidal. Dari gelombang referensi sinusoidal tersebut dibuatlah gelombang sinusoidal tambahan yang bergeser $180^{\circ}$. Kedua gelombang referensi tersebut dimodulasi dengan dua buah sinyal pembawa. Teknik ini dinamakan dengan kontrol unipolar. Hasil modulasi digunakan untuk pensakelaran setiap sakelar daya. Berdasarkan rangkaian blok kendali pada Arduino Due, maka dibuatlah diagram alur pogram seperti ditunjukkan pada Gambar 11.
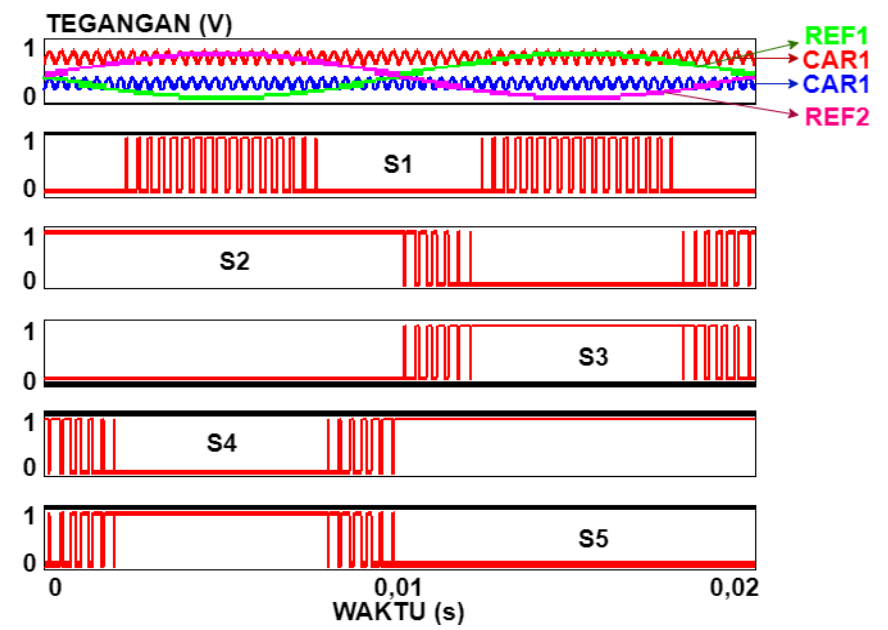

Gambar 10. Bentuk sinyal pensakelaran pada tiap sakelar daya

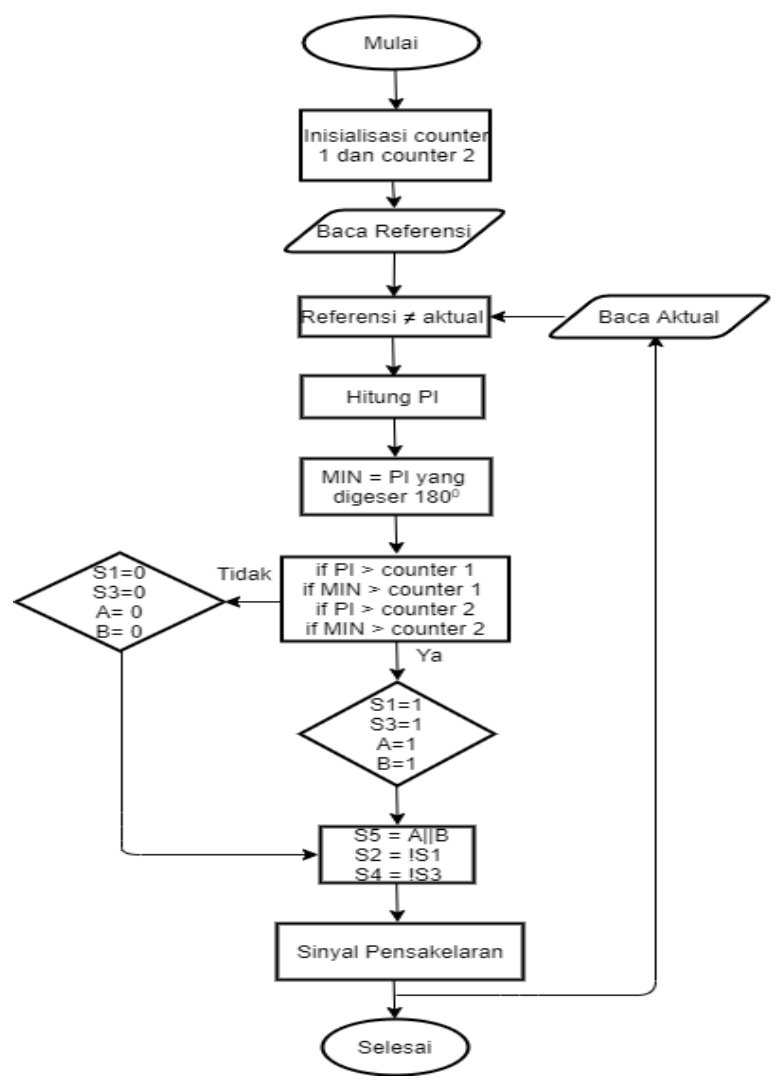

Gambar 11. Diagram alur program 
Gambar 11 menunjukkan alur program yang digunakan. Terdapat satu referensi sinusoidal yang dikontrol dengan PI. Hasil sinyal keluaran PI digeser $180^{\circ}$ sehingga menghasilkan dua buah sinyal kontrol PI yang tergeser $180^{\circ}$. Dua sinyal kontrol ini akan di modulasi dengan counter 1 dan counter 2 dengan tingkatan yang berbeda. Hasil sinyal modulasi ini digunakan untuk pensakelaran setiap sakelar daya. Jika referensi tidak sama dengan aktual maka kontrol PI akan menghitung dan kontrol PI berhenti menghitung jika referensi sama dengan aktual.

\section{HASIL DAN PEMBAHASAN}

Berdasarkan rancangan kontrol dan mode operasi yang telah diuraikan, dibuatlah suatu simulasi komputasi dengan bantuan perangkat lunak Power Simulator dan implementasi perangkat keras untuk me mastikan bahwa konsep yang diteliti berjalan dengan baik menggunakan parameter seperti pada Tabel II dan Tabel III. Tapis induktor digunakan sebagai filter pada keluaran inverter lima tingkat. Keluaran tegangan sebelum dan sesudah tapis induktor dapat dilihat pada Gambar 12.

TABEL II. PARAMETER SimUlasi

\begin{tabular}{|l|l|}
\hline \multicolumn{1}{|c|}{ Parameter } & \multicolumn{1}{c|}{ Nilai } \\
\hline V1 & $35 \mathrm{~V}$ \\
\hline V2 & $35 \mathrm{~V}$ \\
\hline Tapis Induktor & $2 \mathrm{mh}$ \\
\hline Frekuensi Pensakelaran & $5 \mathrm{KHz}$ \\
\hline
\end{tabular}

TABEL III. PARAMETER IMPLEMENTASI

\begin{tabular}{|l|l|}
\hline \multicolumn{1}{|c|}{ Parameter } & \multicolumn{1}{c|}{ Nilai } \\
\hline V1 & $35 \mathrm{~V}$ \\
\hline V2 & $35 \mathrm{~V}$ \\
\hline Tapis Induktor & $2 \mathrm{mh}$ \\
\hline Bohlam & $100 \mathrm{~W}$ \\
\hline Frekuensi Pensakelaran & $5 \mathrm{KHz}$ \\
\hline
\end{tabular}

\section{TEGANGAN (V)}

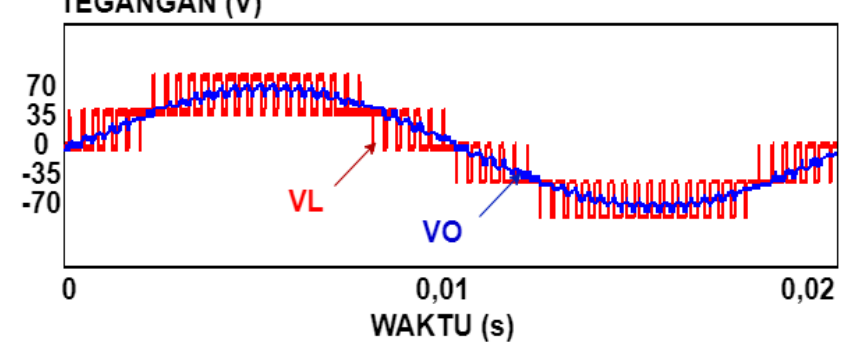

Gambar 12. Hasil simulasi bentuk tegangan keluaran inverter lima tingkat sebelum tapis induktor (VL) dan sesudah tapis induktor (VO)

Kontrol unipolar yang telah dibuat digabungkan dengan kontrol kendali arus. Sinyal referensi diku rangi sinyal aktual akan menghasilkan sinyal error, la lu diolah dengan kontroler jenis PI dan menghasilkan sinyal kontrol. Sinyal kontrol PI dimodulasi dengan sinyal pembawa sehingga menghasilkan modulasi lebar pulsa sinusoidal. Hasil dari simulasi kendali arus dapat dilihat pada Gambar 13.
Strategi kontrol unipolar yang diajukan diimplementasi pada perangkat keras pada Gambar 14. Perangkat keras terdiri atas dua buah buah input DC, DC-DC converter B1212S-1W, driver yang terdiri dari IR2110 dan TLP 250, sensor arus LEM HX 10-p, mikrokontroller Arduino Due, dan beban berupa tiga bohlam $100 \mathrm{~W}$ att.

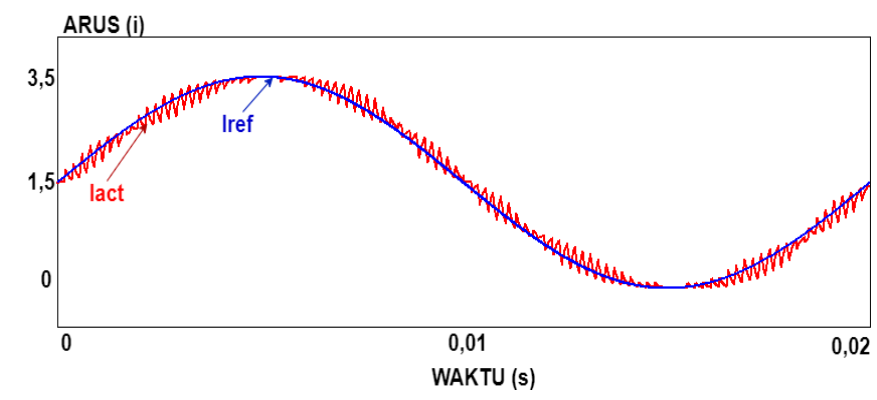

Gambar 13. Hasil simulasi bentuk gelombang inverter lima tingkat arus aktual (biru) dan referensi arus (merah)

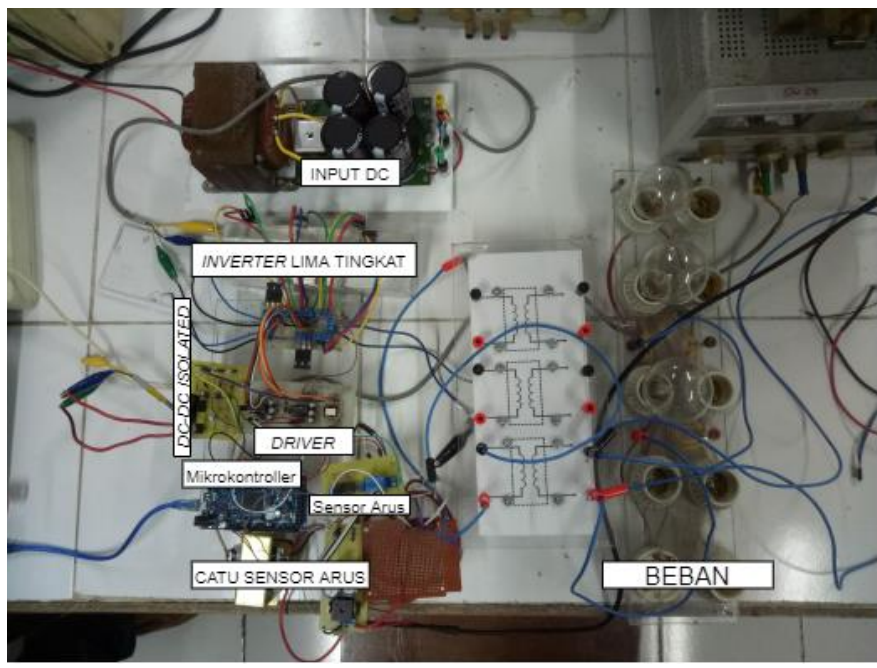

Gambar 14. Perangkat keras inverter lima tingkat

Hasil gelombang keluaran inverter lima tingkat ditunjukkan pada Gambar 15 sampai Gambar 19. Bentuk sinyal pensakelaran pada setiap sakelar daya terdapat pada Gambar 15. Pada Gambar 16 keluaran tegangan antar lengan membentuk tingkatan tegangan, hal ini terjadi karena sinyal modulasi lebar pulsa sinusoidal diimplementasikan pada semua sakelar daya. Tingkatan tegangan yang dihasilkan yaitu 2E dan E pada keluaran antar lengan. Tegangan $2 \mathrm{E}$ didapat dari penjumlahan tegangan V1 dan V2. Tegangan E didapatkan dari nilai tegangan V2. Tapis induktor digunakan pada keluaran inverter lima tingkat. Gambar 17 menunjukkan bentuk tegangan keluaran inverter sebelum dan sesudah tapis induktor. Hasil implementasi pada perangkat keras membuktikan bahwa arus aktual mengikuti arus referensi seperti yang ditunjukkan pada Gambar 18. Nilai arus aktual sebesar 2,24 VRMS dan arus referensi sebesar 2,12 VRMS. Hasil keluaran arus dan tegangan inverter lima tingkat dapat dilihat pada Gambar 19. Nilai arus keluaran inverter lima tingkat sebesar 0,52 Ampere dan tegangan keluaran inverter lima tingkat sebesar 70 VPP. 


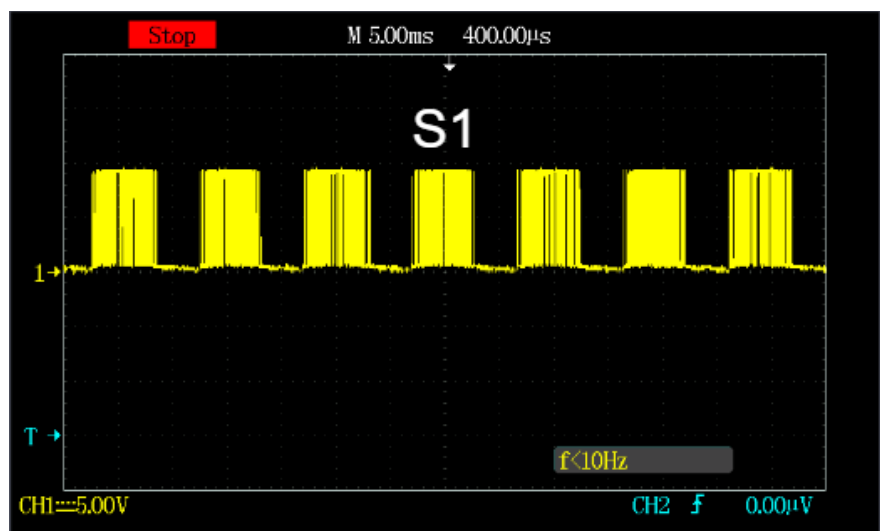

(a)

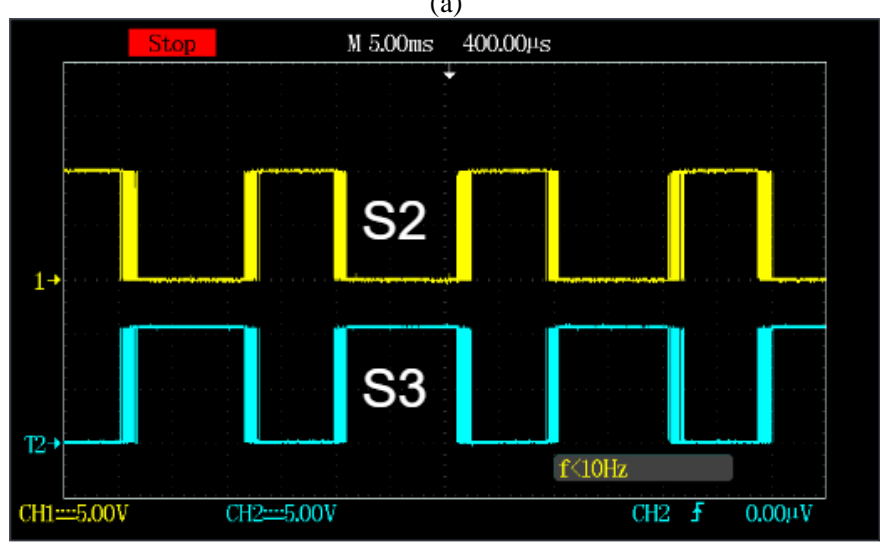

(b)

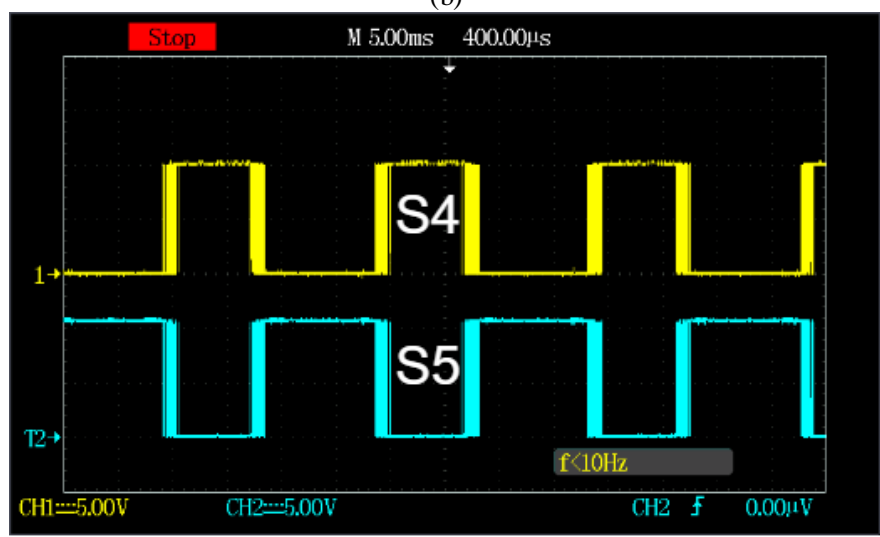

(c)

Gambar 15. Hasil implementasi bentuk gelombang pada pensaklaran inverter lima tingkat (a) sinyal pada sakelar daya S1, (b) sinyal pada sakelar daya S2 dan S3, (c) sinyal pada sakelar daya S4 dan S5

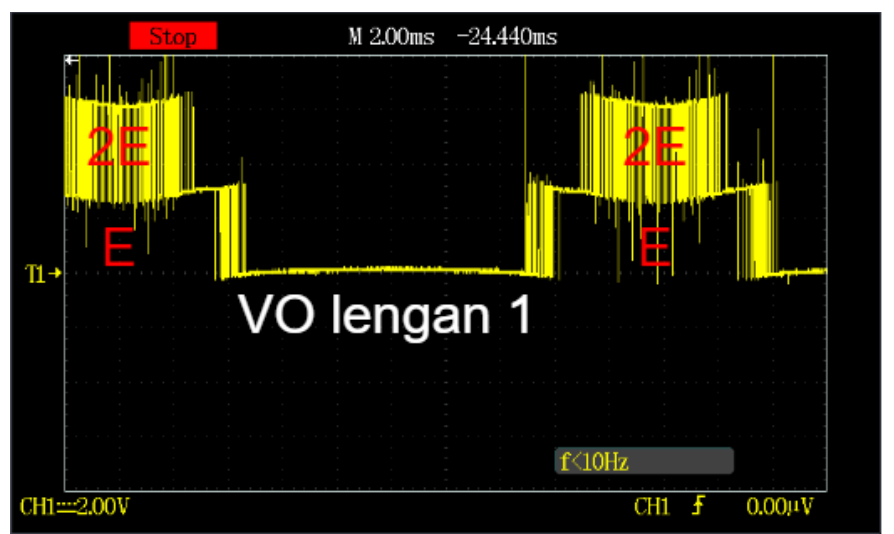

(a)

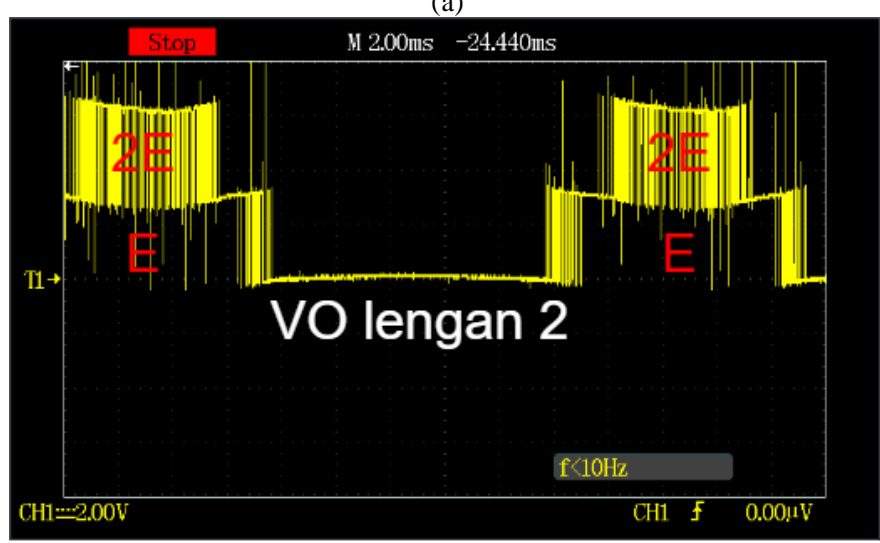

(b)

Gambar 16. Hasil implementasi bentuk gelombang tegangan antar lengan inverter lima tingkat (VO) (a) pada sakelar daya S2 dan S3, (b) pada sakelar daya $\mathrm{S} 3$ dan S4

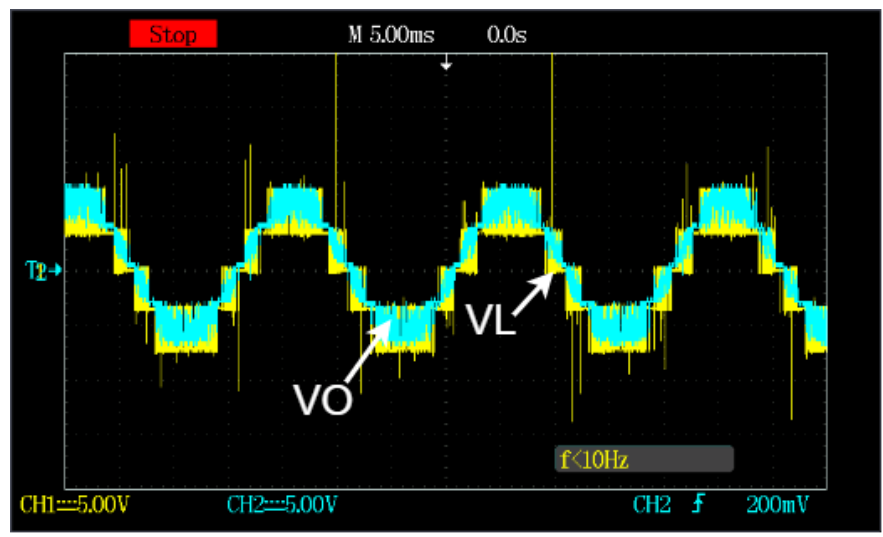

Gambar 17. Hasil implementasi bentuk tegangan inverter lima tingkat sebelum (VL) dan sesudah tapis induktor (VO) 


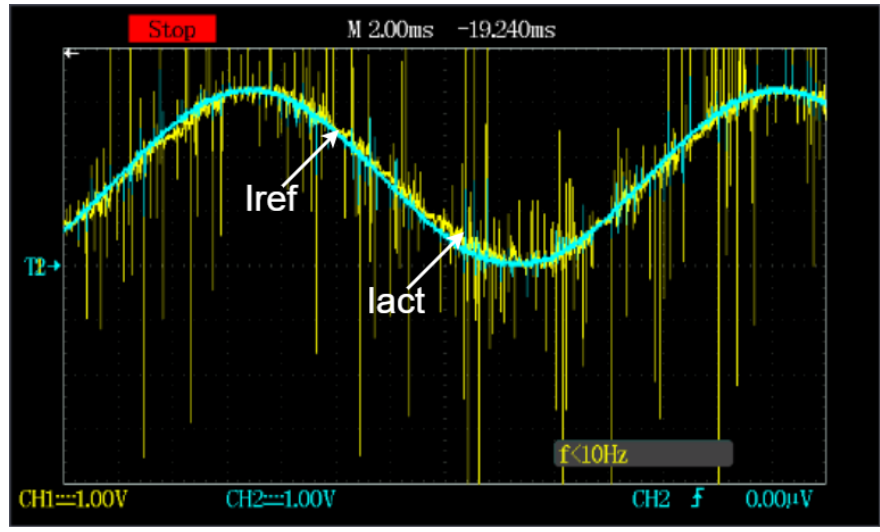

Gambar 18. Hasil implementasi bentuk gelombang arus aktual (Iact) dan referensi arus (Iref) inverter lima tingkat

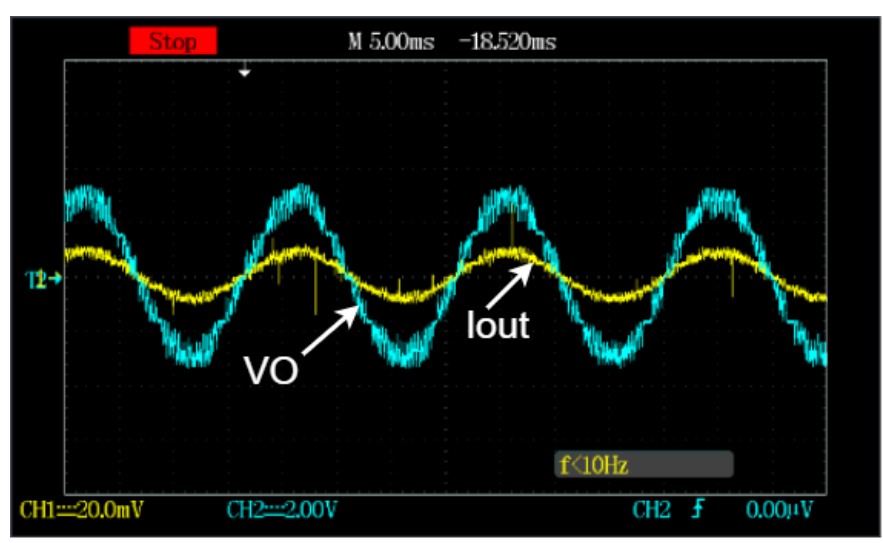

Gambar 19. Hasil implementasi bentuk gelombang arus (Iout) dan tegangan (VO) inverter lima tingkat

Dalam implementasi inverter lima tingkat ini dilakukan pengukuran kandungan $\mathrm{THD}_{\mathrm{i}}$. Pada Gambar 20 didapatkan $\mathrm{THD}_{\mathrm{i}}$ sebesar $4,01 \%$. Hasil pengukuran ini memenuhi standart IEEE 519 karena di bawah 5\%.

\begin{tabular}{|c|c|c|}
\hline Frekuensi : $50 \mathrm{~Hz}$ (AUTO) & \multicolumn{2}{|c|}{ Rentang: $\mathrm{ACA}$ (AUTO) } \\
\hline THD-F : $4.01 \%$ & THD-R : $4.01 \%$ & 1l \\
\hline & $1:$ & $0.520 \mathrm{~A}$ \\
\hline & 2: & $0.004 \mathrm{~A}$ \\
\hline & $3:$ & $0.012 \mathrm{~A}$ \\
\hline
\end{tabular}

Gambar 20. Hasil implementasi $\mathrm{THD}_{\mathrm{i}}$ Inverter lima tingkat

Inverter yang digunakan pada sistem on-grid lazimnya adalah H-bridge inverter dengan frekuensi tinggi untuk mendapatkan $\mathrm{THD}_{\mathrm{i}}$ yang rendah [18]. Inverter bertingkat dengan frekuensi rendah menggunakan lima sakelar daya dapat digunakan sebagai alternatif [19]. Inverter lima tingkat dengan lima sakelar daya memiliki efisiensi rata-rata sebesar $82,14 \%$. Berdasarkan hasil pengujian, inverter lima tingkat dengan lima sakelar daya yang arus keluarannya dikendalikan mampu mengirimkan daya ke grid sesuai dengan standart IEEE 519. Standart $\mathrm{THD}_{\mathrm{i}}$ IEEE 519 sebesar 5\% [20]. Daya yang dikirimkan sebesar 36,4 Watt. Daya yang dikirimkan berupa besaran arus sebesar 0,52 Ampere.

\section{PENUTUP}

Inverter lima tingkat dengan menggunakan lima buah sakelar daya yang dikendalikan arus keluarannya mampu mengirimkan daya ke grid satu fasa. Inverter lima tingkat menghasilkan tegangan sebesar 70 VPP dan arus 0,52 A mpere. Daya yang dikirimkan sebesar 36,4 Watt. Daya yang dikirimkan berupa besaran arus sebesar 0,52 Ampere. Kandungan $\mathrm{THD}_{\mathrm{i}}$ yang dihasilkan inverter lima tingkat sebesar 4,01\% dan memenuhi standart IEEE 519 yaitu di bawah $5 \%$.

\section{UCAPAN TERIMA KASIH}

Peneliti mengucapkan banyak terima kasih atas pembiayaan dari Kementrian Riset dan Teknologi/Badan Riset dan Inovasi Nasional dalam skema Penelitian Dasar Unggulan Perguruan Tinggi tahun anggaran 2020 dengan Nomor SK: 010/LL6/PG/SP2H.1/AMD/PENELITIA N/2020

\section{REFERENSI}

[1] P. Pangaribuan, D. Darlis, and R. Prabudi, "Implement ation of the Sun Tracker System with fuzzy logic on solar panels," VOLT J. Ilm. Pendidik. Tek. Elektro, vol. 3, no. 2,pp.78-84,2018.

[2] S. Y. Panggabean, "Rancang Bangun Inverter Satu Fasa Menggunakan Teknik High Voltage PWM (Pulse Width Modulation)," ELECTRICIAN-Jurnal Rekayasa dan Teknologi Elektro, vol. 11, no. 2, pp. 1-9, 2017.

[3] R. Hariyati, M. N. Qosim, and A. W. Hasanah, "Konsep Fotovoltaik Terintegrasi On Grid dengan Gedung STT PLN," Energi dan Kelistrikan, vol. 11, no. 1, pp. 17-26, 2019.

[4] A. Ketabi and S. E. Tabatabaei M., "Photovoltaic single-stage grid tied inverter with One-Cycle Control," 6th Аnnu. Int. Power Electron. Drive Syst. Technol. Conf. PEDSTC, pp. 257-262, 2015.

[5] F. Xie, Z. Luo, D. Qiu, B. Zhang, Y. Chen, and L. Huang, "Study on a simplified structure of a two-stage grid-connected photovoltaic system for parameter design opt imization," Energies, vol. 12, no. 11, pp. 1-16, 2019.

[6] F. A. Samman, R. Ahmad, and M. Mustafa, "Perancangan, Simulasi dan Analisis Harmonisa Rangkaian Inverter Satu Fasa," J. Nas. Tek Elektro dan Teknol. Inf., vol.4, no. 1, pp. 62-70, 2015.

[7] J. Ismiyadinata, H. Yuliansyah, M. R. K. Aziz, and A. S. Rohman, "Desain dan Implementasi Inverter Satu Fasa 400 Watt dengan Metode Switching High Frequency," J. Sci. Appl. Technol., vol. 3, no. 1, pp. 9$16,2019$.

[8] A. Sudarsanan, R. Roopa, and S. Sanjana, "Comparison of Conventional \& New Multilevel Inverter Topology," Intemational Journal of Scientific \& Engineering Research, vol. 6, no. 2, pp. 330334, 2015.

[9] I. Kristiawan and L. Heru Prat omo, "Design and simulation full control strategy in single-phase five-level inverter," in J. Phys. Conf. Ser 1444, pp. 1-7, 2020.

[10] H. Semendawai and T. Sutikno, "Pemodelan Neutral Point ClampedMultilevel Inverter Tiga Fasa Menggunakan Metode Phase Disposition Pulse Widh Modulation Sinyal Pembangkit Sumber Tegangan Rangkaian Tegangan Keluaran," Jumal Ilmu Teknik Elektro Komputer dan Informatika (JITEKI), vol. 4, no. 1, pp. 28-34, 2018.

[11] S. Khadse, R. Mendole, and A. Pandey, "A 5-Level Single Phase Flying Capacit or Multilevel Inverter," Int. Res. J. Eng. Technol., vol. 4, no. 2 , pp. 348-352, 2017.

[12] I. Husnaini, "Komparasi Multilevel Inverter Satu Fasa,"Jumal EECIS, vol. 13, no. 2, pp. 95-99, 2019.

[13] S. B G, C. Srikanth, and V. Yatnalli, "Review on Multi Level Inverter Topologies and Control Strategies for Solar Power Conversion," Emit. Int. J. Eng. Technol., vol. 8, no. 2, pp. 295-315, 2020. 
[14] B. A. Yomahudaya and T. Sutikno, "Pembangkit Sinyal SPWM untuk Multilevel Inverter Satu Fasa Lima Tingkat Berbasis Mikrokontroler AT mega32," J. Ilm. Tek. Elektro Komput. dan Inform., vol. 3, no. 2, pp. 73-81, 2017.

[15] M. Azri, A. Alias, Musa, A. A. Nazmudi, and Z. Rasin, "Comparison performance of nine level multilevel inverter using bipolar and unipolar switching schemes," Univers. J. Electr. Electron. Eng., vol. 6, no. 5, pp. 8-22, 2019.

[16] A. J. Gray, B. M. Vargheese, and M. G. James, "T wo Stage Five Level Inverter for Grid Connected Application," Int. J. Eng. Tech., vol. 2, no. 5, pp. 65-70, 2016.

[17] L. H. Pratomo, "One Leg Control Strategy in Single-Phase Five-Level Inverter," in 2019 International Symposium on Electrical and Electronics Engineering (ISEE),pp. 216-220, 2019.

[18] L. Hassaine and M. R. Bengourina, "Design and control technique for single phase bipolar H-bridge inverter connected to the grid," Int. J. Electr. Comput. Eng., vol. 10, no. 3, pp. 3057-3065, 2020.

[19] H. Bhattacherjee and J. Nakka, "A single-phase cascaded H-Bridge inverter for grid-tie photovoltaic system addressing the problem of unbalances in H-Bridge cells," in Int. Conf. Microelectron. Comput. Commun.MicroCom, pp. 1-6, 2016.

[20] I. P. Adi Wirajaya, I. W. Rinas, and I. W. Sukerayasa, "Studi Analisa Pengaruh Total Harmonic Distortion (THD) terhadap Rugi-Rugi, Efisiensi, dan Kapasitas Kerja Transformator pada Penyulang Kerobokan,”J. SPEKTRUM, vol. 6, no.2, pp. 121,2019. 